\title{
Market Efficiency and Idiosyncratic Volatility in Vietnam
}

\author{
Ngoc Tho Tran ${ }^{1} \&$ Thi Ngoc Trang Nguyen ${ }^{1}$ \\ ${ }^{1}$ School of Finance, University of Economics Ho Chi Minh City, Vietnam \\ Correspondence: Ngoc Tho Tran, School of Finance, University of Economics Ho Chi Minh City, Ho Chi Minh \\ City, Vietnam. E-mail: thotcdn@ueh.edu.vn
}

Received: February 14, 2015

Accepted: May 17, 2015

Online Published: May 22, 2015

doi:10.5539/ijbm.v10n6p216

URL: http://dx.doi.org/10.5539/ijbm.v10n6p216

\begin{abstract}
We study idiosyncratic volatility in the Vietnamese stock market between July 2007 and February 2015. We show that there is no relationship between the idiosyncratic volatility and average returns in the Vietnamese market. Our results also indicate that neither the aggregate market volatility, the aggregate idiosyncratic volatility nor can predict market returns. Finally, we find no trend in idiosyncratic volatility and a decreasing trend of market volatility over the sample period. In addition, we find strong evidence of both short as well as long term reversal in Vietnam stock market during the sample period.
\end{abstract}

Keywords: idiosyncratic volatility

\section{Introduction}

The relation between risk and return has been an important topic in the literature. Classical asset pricing theory predicts that riskier assets should command higher expected returns. Total risk can be decomposed into systematic risk and idiosyncratic risk. This theory also prescribes that idiosyncratic risk, which represents the uncertainty of a single firm, should not be priced because investors can diversify idiosyncratic risk. Idiosyncratic risk can be diversified away through constructing portfolios consisting of different securities. Under the assumption of complete market, investing in securities is frictionless, which means the investors can buy and sell securities without transaction costs. Thus, a rational agent can diversify idiosyncratic volatility away and should have no preferences regarding idiosyncratic volatility.

In theory, idiosyncratic volatility is orthogonal to the stochastic discount factor, which makes it irrelevant for expected returns. Thus in a complete market, agents' decisions should not be affected by idiosyncratic volatility as it has no impact on investors' welfare. However in the real world, markets are incomplete and far from perfect. For example, what if investors are constrained from holding diversified portfolios? The question of whether idiosyncratic risk has predicting power for the stock returns plays an important role in the asset pricing literature. Much of the empirical evidence poses a major challenge to the traditional asset pricing theory. Different hypotheses have been proposed to explain the idiosyncratic volatility effect. Some of them concentrate on the features of the stock return distribution, such as its skewness. Others consider the behavioural characteristics of investors, including the proportion of retail investors and investor attention. While the empirical evidence is mixed, the inconsistent findings regarding pricing of idiosyncratic risk and its potential direction of the impact warrant further examination.

In this paper we study idiosyncratic volatility in the Vietnamese stock market from July 2007 to February 2015. The motivation to focus on the Vietnamese stock market is due to the fact that it one of the most rapidly developing emerging markets in the world. The first stock exchange in Vietnam has been opened in 2000 in Ho Chi Minh City and the second one in Hanoi in 2005. The number of listed companies has increased from just five in 2000 to 841 by end of 2014. The stock market has also substantially contributed to the development of Vietnam economy with its market capitalization accounting for 33\% of GDP in 2014. The size of the Vietnamese stock market is considerably smaller than that of neighbouring countries, including Thailand, Philippines, Indonesia and Singapore, where the ratio of market capitalization to GDP is well above $100 \%$, which implies that the Vietnamese stock market has enormous growth potential. The remainder of this paper is organized as follows. In Section 2 we review the literature. In Section 3 we describe the data and methodology. Results are presented in Section 4. Finally, Section 5 concludes the paper. 


\section{Literature Review}

Idiosyncratic volatility represents firm-specific risk which is not associated with the market. Standard asset pricing theory suggests that it should not be priced, because firm-specific risk can be diversified away. In other words, under the assumption of a complete frictionless market, investors should be compensated only for bearing systematic risk. The empirical evidence on the relationship between the idiosyncratic volatility and returns is mixed. Some researchers find a positive relationship (e.g. Lehmann, 1990), while others find no relationship (e.g. Bali, Cakici, Yan, \& Zhang, 2005) or a negative relationship (e.g. Ang, Hodrick, Xing, \& Zhang, 2006). Another aspect of idiosyncratic volatility studied in the literature is its evolution over time. For example, Campbell, Lettau, Malkiel, \& Xu, 2001) report that there is an upward trend in the idiosyncratic volatility in U.S. market between 1962 and 1997, wheres Bekaert, Hodrick and Zhang (2012) report that there is no trend in the idiosyncratic volatility in U.S. market between 1964 and 2005. In the literature, idiosyncratic volatility is also related to a number of market and firm characteristics. These include future earnings (Jiang, Xu, \& Yao, 2009), short sale constraints (Nagel, 2005; Boehme, Danielsen, Kumar, \& Sorescu, 2009), financial distress (Avramov, Chordia, Jostova, \& Philipov, 2013), preference for positive skewness of returns (Boyer, Mitton, \& Vorkink 2010); Bali, Cakici \& Whitelaw, 2011) or systematic risk exposure (Barinov, 2011; Chen \& Petkova, 2012) to name but a few.

Ang, Hodrick, Xing, and Zhang (2006) are the first to examine the idiosyncratic volatility at the firm level using portfolio sorts on the basis of idiosyncratic volatility relative to the Fama and French (1993) model. They use a sample of AMEX, NASDAQ, and NYSE stocks from 1963 to 2000. At the end of each month, they rank firms on the basis of idiosyncratic volatility in the past month and form five value-weighted portfolios which are held for one month. They find a strong negative relationship between the lagged idiosyncratic volatility and average returns. Specifically, low idiosyncratic volatility stocks outperform high idiosyncratic volatility stocks by 131 basis points per month on average after adjusting for the Fama and French (1993) risk factors. Their result is both statistically and economically significant and robust to controlling for value, size, leverage, liquidity, volume, turnover, bid-ask spread, coskewness, dispersion in analyst forecasts, and momentum. Moreover, the idiosyncratic volatility effect is robust to different portfolio formation periods and different holding periods. Ang, Hodrick, Xing, and Zhang (2006) also control for business cycle and show that during NBER expansions (recessions) low idiosyncratic volatility stocks outperform high idiosyncratic volatility stocks by 125 (179) basis points per month on average after adjusting for the Fama and French (1993) risk factors. Finally, the idiosyncratic volatility effect also persists in bull and bear markets as well as during volatile and stable periods.

Ang, Hodrick, Xing, and Zhang (2006) note that their finding cannot be explained by the exposure to the aggregate volatility risk and contrasts with earlier research. For example, Lintner (1965), Tinic and West (1986), Lehmann (1990) as well as Malkiel and Xu (1997) find that the idiosyncratic volatility is positively related to future returns. Goyal and Santa-Clara (2003) study the relationship between the stock market returns and average stock variance measured as the equally-weighted average of the variances of all the stocks in the cross-section. They use a sample of AMEX, NASDAQ, and NYSE stocks from 1963 to 1999. They find a significant positive relationship between the average stock variance and stock market returns in predictive regressions while the variance of the stock market has no predicting power for the stock market returns. They also point out that the stock market returns predictability of the average stock variance is consistent with time-varying risk premia models based on background risk and investor heterogeneity. Bali, Cakici, Yan and Zhang (2005) dispute the findings of Goyal and Santa-Clara (2003). Using a sample of AMEX, NASDAQ, and NYSE stocks from 1963 to 2001, they and find that the result of Goyal and Santa-Clara (2003) is driven by small stocks and liquidity premium. Moreover, they find no significant relationship between stock market returns and average stock variance.

Merton (1987), Barberis and Huang (2001), Malkiel and Xu (2004) as well as Ewens, Jones and Rhodes-Kropf (2013) develop models that predict that stocks with higher idiosyncratic volatility should earn higher expected returns in order to compensate investors for inability to diversify. In early work, Lintner (1965) finds that the variance of the residuals from the CAPM is significant in explaining the cross-section of the average returns. Tinic and West (1986) as well as Malkiel and Xu (1997) provide empirical evidence of a positive relationship between the idiosyncratic volatility and average returns. Tinic and West (1986) report a positive coefficient on idiosyncratic volatility in cross-sectional regressions of returns between 1935 and 1982. Lehmann (1990) studies the residual risk and suggests that the Black, Jensen and Scholes (1972) methodology is more efficient in estimating the residual risk effect compared to the Fama and MacBeth (1973) methodology. He also reports a statistically significant coefficient on residual risk in cross-sectional regressions of returns between 1926 and 1987. Merton (1987) extends the CAPM to account for the effects of incomplete information. Using this 
assumption, Merton (1987) shows that expected returns increase with systematic risk, idiosyncratic risk and size. Barberis and Huang (2001) incorporate loss aversion and narrow framing into an asset-pricing framework. They show that in the equilibrium, while the risk-free interest rate is low, aggregate stock returns are characterized by high mean and volatility as well as moderate predictability in the time series. Malkiel and Xu (2004) extend the CAPM to show that the idiosyncratic risk will affect asset returns if investors are not able to hold the market portfolio which is also supported by the empirical evidence. Moreover, Malkiel and Xu (2004) use a sample of AMEX, NASDAQ, and NYSE stocks from 1925 to 2000 and find that the idiosyncratic volatility helps to explain the cross-section of expected returns. Ewens, Jones and Rhodes-Kropf (2013) provide evidence that the idiosyncratic risk is priced for private equity investments.

In a subsequent study, Ang, Hodrick, Xing, and Zhang (2009) show that the idiosyncratic volatility effect is also present in 23 developed markets. They report that low idiosyncratic volatility stocks outperform high idiosyncratic volatility stocks by 131 basis points per month on average after adjusting for the Fama and French (1993) risk factors. They also find that the negative returns differential between the high idiosyncratic volatility and low idiosyncratic volatility stocks of U.S market co-moves with those of the remaining 22 countries. Ang, Hodrick, Xing, and Zhang (2009) point out that the idiosyncratic volatility effect in U.S. stock market cannot be explained by information asymmetry, percentage of zero returns, analyst coverage, institutional ownership, delay, and skewness. Bekaert, Hodrick and Zhang (2012) study the aggregate idiosyncratic volatility in 23 developed markets. They find that the idiosyncratic volatility is highly correlated across countries. They report that there is no upward trend in the idiosyncratic volatility in 23 countries and that the idiosyncratic volatility follows a stationary regime-switching process.

Campbell, Lettau, Malkiel, and Xu (2001) document the upward trend in the idiosyncratic volatility in U.S. stock market between 1962 and 1997. On the other hand, market volatility and industry volatility during this period remains stable and shows no trend. In Campbell, Lettau, Malkiel, and Xu (2001), the idiosyncratic volatility is computed as the weighted average of firm-level volatility across all firms. This methodology avoids the estimation of industry and firm-level betas to estimate the market, industry, and firm-level volatility. Xu and Malkiel (2003) suggest that the upward trend in the idiosyncratic volatility between 1952 and 1998 is related to increased institutional ownership. They also report a positive relationship between the idiosyncratic volatility and earnings growth. Wei and Zhang (2006) point out that the return on equity and its volatility are determinants of the upward trend in the idiosyncratic volatility. They find that declining return on equity and increasing volatility of the return on equity contribute to the upward trend in the idiosyncratic volatility. Brown and Kapadia (2007) show that the upward trend in the idiosyncratic volatility is a result of newly listed firms being more risky. They argue that firms becoming publicly traded between 1963 and 2004 are more risky compared to those already publicly traded. Thus the composition of publicly traded firms has changed with more risky firms becoming publicly traded which explains the increase in the idiosyncratic volatility over time.

Cao, Simin and Zhao (2008) provide a theoretical explanation of upward trend in the idiosyncratic volatility. They argue that growth options available to managers explain the upward trend in the idiosyncratic volatility. The empirical evidence shows that accounting for growth options eliminates or reverses the upward trend in the aggregate idiosyncratic volatility. Irvine and Pontiff (2009) find that the trend in the volatility of idiosyncratic cash-flows mimics the trend in the idiosyncratic volatility and suggest that the upward trend in the idiosyncratic volatility is related to increased competition in the economy. Fink, Fink, Grullon and Weston (2010) present evidence that the increase in the idiosyncratic volatility in the 1990s is the result of an increase in the number of newly listed firms as well as newly listed firms being younger. They also find that after controlling for firm age there is no evidence that investor sentiment is responsible for the increase in the idiosyncratic volatility in the late 1990s. Brandt, Brav, Graham and Kumar (2010) argue that the increase in the idiosyncratic volatility through the 1990s was temporary and partially induced by retail investors. They demonstrate that by 2003 the idiosyncratic volatility has returned to the pre-1990s levels.

\section{Data and Methodology}

Daily and monthly stock return data from July 2007 to February 2015 have been collected from Datastream together with market value and book-to-market value ratio. Our sample consists of 889 firms. We use State Bank of Vietnam's prime rate as the risk-free interest rate. In Table 1 we report cross-sectional averages of daily firm returns, market value and book-to-market value ratio. 
Table 1. Summary statistics of the data

\begin{tabular}{llll}
\hline & Return & Market value & B/M ratio \\
\hline Mean & $0.04 \%$ & 75.9750 & 1.4724 \\
Median & $0.00 \%$ & 70.6838 & 1.4178 \\
Standard Deviation & $4.10 \%$ & 24.5501 & 0.7442 \\
\hline
\end{tabular}

The average daily return is positive and equal to $0.04 \%$. The average market value is just over 75 million USD, whereas the average book-to-market value ratio is almost $150 \%$.

First, we construct Fama and French (1993) risk factors for Vietnam. The three factors are MKT, SMB and HML. MKT is the market factor defined as the average value-weighted market return minus the risk free rate. SMB is the size factor defined as the average value-weighted return of small firms minus average return of big firms. HML is the value factor defined as the average value-weighted return of value firms minus average return of growth firms. At the end of June of each year t firms are ranked into terciles. The breakpoints are the 30th and 70th percentiles of the book-to-market value ratio at the end of December of year t-1. We also rank firms on size. The breakpoint is the median of the market value at the end of June of year $t$. We then form six portfolios from the intersections of the three value and two size groups and hold them for one year. Summary statistics of the daily Fama and French (1993) risk factors for US and Vietnam between July 2007 and February 2015 are presented in Table 2.

Table 2. Summary statistics of the daily Fama and French (1993) factors

\begin{tabular}{lllllll}
\hline & US & \multicolumn{5}{c}{ VN } \\
\cline { 2 - 7 } & MKT & SMB & HML & MKT & SMB & HML \\
\hline Mean & $0.24 \%$ & $0.01 \%$ & $-0.01 \%$ & $-0.01 \%$ & $0.01 \%$ & $0.01 \%$ \\
Median & $0.21 \%$ & $0.02 \%$ & $-0.01 \%$ & $0.00 \%$ & $0.00 \%$ & $0.00 \%$ \\
Standard Deviation & $1.49 \%$ & $0.60 \%$ & $0.64 \%$ & $1.66 \%$ & $0.81 \%$ & $0.96 \%$ \\
Skewness & 0.04 & 0.04 & 0.33 & -0.10 & 0.42 & -0.35 \\
Kurtosis & 9.95 & 7.82 & 9.62 & 4.88 & 6.43 & 8.29 \\
\hline
\end{tabular}

We find that over the past seven and a half years $\mathrm{VN}$ market exhibit negative average daily market return of $-0.01 \%$ whereas US market exhibit positive average daily market return of $0.24 \%$. We note that while the average daily return on the SMB portfolio is the same for both markets, the average daily return on the HML portfolio is positive for VN market but negative for US market. We also find significantly higher volatility for all portfolios in the VN market compared to the US market. Moreover, we note that US portfolios have positively skewed returns, whereas those in the VN market are mostly negatively skewed. Finally, US portfolios exhibit much higher kurtosis compared to the $\mathrm{VN}$ ones.

Next, we calculate idiosyncratic volatility which is defined as the standard deviation of the residuals from the Fama and French (1993) model. At the end of each month we regress daily excess returns of individual firms on daily MKT, SMB and HML. We require least 15 daily observations to estimate the idiosyncratic volatility. In Table 3 we present the descriptive statistics of the idiosyncratic volatility. $\mathrm{IV}^{\mathrm{EW}}$ and $\mathrm{IV}^{\mathrm{VW}}$ are equally-weighted and value-weighted aggregate idiosyncratic volatility. MVOL represents the value-weighted market volatility and is computed on a monthly basis as the standard deviation of daily value-weighted market returns in the past 22 days.

Table 3. Summary statistics of the idiosyncratic volatility

\begin{tabular}{llll}
\hline & $\mathrm{IV}^{\mathrm{VW}}$ & $\mathrm{IV}^{\mathrm{EW}}$ & $\mathrm{VOL}$ \\
\hline Mean & 0.0165 & 0.0244 & 0.0314 \\
Median & 0.0157 & 0.0242 & 0.0297 \\
Standard Deviation & 0.0089 & 0.0052 & 0.0073 \\
\hline
\end{tabular}

We find that the mean of $\mathrm{IV}^{\mathrm{EW}}$ is higher than that of $\mathrm{IV}^{\mathrm{VW}}$, which means that smaller firms have a higher idiosyncratic volatility. This result is consistent with that reported in the literature for the US market and is explained by the fact that smaller firms are riskier and thus have a higher idiosyncratic volatility. We note that 
$\mathrm{IV}^{\mathrm{EW}}$ and $\mathrm{IV}^{\mathrm{VW}}$ are positively correlated, with a correlation coefficient of 0.4056 . MVOL is positively correlated with both $\mathrm{IV}^{\mathrm{VW}}$ and $\mathrm{IV}^{\mathrm{EV}}$ with correlation coefficients of 0.4688 and 0.7819 respectively.

\section{Results}

We first use portfolio sorts to examine the idiosyncratic volatility effect in the Vietnamese stock market. At the end of each month firms are ranked into terciles. The breakpoints are the 30th and 70th percentiles of the past month idiosyncratic volatility. The portfolio is re-sorted every month from August 2007 to Febraury 2015. In Table 4 we display average monthly returns, market value, book-to-market value ratio, monthly excess returns computed with respect to the Fama and French (1993) three-factor model as well as the estimated regression coefficients from this model. In Panel A we report results for value-weighted portfolios whereas in Panel B we report the corresponding results for equally-weighted portfolios. The t-statistic is shown in parentheses.

Table 4. Idiosyncratic volatility tercile portfolio sorts

\begin{tabular}{|c|c|c|c|c|c|c|c|c|c|}
\hline & $\begin{array}{l}\text { Monthly } \\
\text { return }\end{array}$ & $\begin{array}{l}\text { Market } \\
\text { value }\end{array}$ & $\begin{array}{l}\mathrm{B} / \mathrm{M} \\
\text { ratio }\end{array}$ & $\begin{array}{l}\text { Monthly } \\
\text { return }\end{array}$ & excess & $\beta_{\text {MKT }}$ & $\beta_{\mathrm{SMB}}$ & $\beta_{\mathrm{HML}}$ & $\begin{array}{l}\text { Adjusted } \\
\mathrm{R}^{2}\end{array}$ \\
\hline \multicolumn{10}{|c|}{ Panel A: Value-Weighted } \\
\hline Low IV & $1.84 \%$ & 59.7840 & 1.2522 & $\begin{array}{l}1.61 \% \\
(1.3546)\end{array}$ & & $\begin{array}{l}0.8668 \\
(7.2605)\end{array}$ & $\begin{array}{l}0.2058 \\
(0.9339)\end{array}$ & $\begin{array}{l}-0.4224 \\
(-1.8223)\end{array}$ & 0.4234 \\
\hline Medium IV & $1.27 \%$ & 60.9895 & 1.2456 & $\begin{array}{l}1.11 \% \\
(3.5556)\end{array}$ & & $\begin{array}{l}0.9493 \\
(30.3146)\end{array}$ & $\begin{array}{l}-0.0448 \\
(-0.7755)\end{array}$ & $\begin{array}{l}0.2650 \\
(4.3586)\end{array}$ & 0.9130 \\
\hline High IV & $2.70 \%$ & 62.4271 & 1.2537 & $\begin{array}{l}2.13 \% \\
(2.4195)\end{array}$ & & $\begin{array}{l}0.9570 \\
(10.8584)\end{array}$ & $\begin{array}{l}0.7714 \\
(4.7408)\end{array}$ & $\begin{array}{l}0.6144 \\
(3.5903)\end{array}$ & 0.6508 \\
\hline High-Low & $\begin{array}{l}0.86 \% \\
(0.5414)\end{array}$ & $\begin{array}{l}2.6431 \\
(0.4922)\end{array}$ & $\begin{array}{l}0.0015 \\
(0.1468)\end{array}$ & $\begin{array}{l}0.51 \% \\
(0.3546)\end{array}$ & & $\begin{array}{l}0.0902 \\
(0.6210)\end{array}$ & $\begin{array}{l}0.5656 \\
(2.1085)\end{array}$ & $\begin{array}{l}1.0368 \\
(3.6752)\end{array}$ & 0.1842 \\
\hline \multicolumn{10}{|c|}{ Panel B: Equally-Weighted } \\
\hline Low IV & $0.91 \%$ & 59.7840 & 1.2522 & $\begin{array}{l}0.59 \% \\
(0.8582)\end{array}$ & & $\begin{array}{l}0.8936 \\
(12.9854)\end{array}$ & $\begin{array}{l}0.3146 \\
(2.4764)\end{array}$ & $\begin{array}{l}0.0242 \\
(0.1810)\end{array}$ & 0.6837 \\
\hline Medium IV & $0.69 \%$ & 60.9895 & 1.2456 & $\begin{array}{l}0.31 \% \\
(1.2839)\end{array}$ & & $\begin{array}{l}1.0526 \\
(43.2585)\end{array}$ & $\begin{array}{l}0.5159 \\
(11.4834)\end{array}$ & $\begin{array}{l}0.4629 \\
(9.7970)\end{array}$ & 0.9618 \\
\hline High IV & $1.60 \%$ & 62.4271 & 1.2537 & $\begin{array}{l}0.87 \% \\
(2.0567)\end{array}$ & & $\begin{array}{l}0.9828 \\
(23.1659)\end{array}$ & $\begin{array}{l}1.1791 \\
(15.0541)\end{array}$ & $\begin{array}{l}0.5268 \\
(6.3948)\end{array}$ & 0.9129 \\
\hline High-Low & $\begin{array}{l}0.69 \% \\
(0.6514)\end{array}$ & $\begin{array}{l}2.6431 \\
(0.4922)\end{array}$ & $\begin{array}{l}0.0015 \\
(0.1468)\end{array}$ & $\begin{array}{l}0.28 \% \\
(0.3288)\end{array}$ & & $\begin{array}{l}0.0892 \\
(1.0401)\end{array}$ & $\begin{array}{l}0.8645 \\
(5.4591)\end{array}$ & $\begin{array}{l}0.5026 \\
(3.0177)\end{array}$ & 0.3508 \\
\hline
\end{tabular}

We find that the lowest idiosyncratic volatility stocks are, on average, smaller in size. We also find that the low idiosyncratic volatility portfolio has lower exposure to market, SMB as well as HML factors compared to the high idiosyncratic volatility portfolio. We do not find a statistically significant negative relationship between the idiosyncratic volatility and average returns, as returns differentials between high idiosyncratic volatility and low idiosyncratic volatility portfolios are positive, but statistically insignificant. The Fama and French (1993) three-factor model is able to explain returns of both medium IV and high IV portfolios because all betas are statistically significant. However, for the low IV portfolio $\beta_{\mathrm{MKT}}$ is always statistically significant, but $\beta_{\mathrm{SMB}}$ of the value-weighted portfolio and $\beta_{\mathrm{HML}}$ of the Equally-Weighted portfolio are not statistically significant.

We further examine the robustness of the above findings using Fama-MacBeth (1973) regression. We control for firm size, market-to-book value ratio, reversal, momentum and firms' beta. To control for firm size we use the logarithm of firm's market value. This control is important as Banz (1981) has shown that small firms tend to outperform large firms. Similarly, the control for market-to-book ratio is important because Fama and French (1992) have shown that value firms tend to outperform growth firms. We control for reversal because DeBondt and Thaler (1985) have shown that past long-term losers tend to outperform past long-term winners. Reversal variable in month $t$ is defined as the return in month $t-1$. We control for momentum because Jegadeesh and Titman (1993) have shown that past short-term winners tend to outperform past short-term losers. Momentum variable in month $\mathrm{t}$ is defined as the cumulative return between month $\mathrm{t}-12$ and month $\mathrm{t}-2$. Beta is obtained from the CAPM using 22 daily observations. Each month we regress monthly firm excess return on a series of control variables described above. The results of Fama-MacBeth (1973) regression are presented in Table 5. The coefficients represent time series averages of regression coefficients obtained in monthly cross-sectional regressions. The t-statistic is shown in parentheses. 
Table 5. Fama-MacBeth (1973) regression

\begin{tabular}{lllllll}
\hline Intercept & IV & MV & B/M & Reversal & Momentum & Beta \\
\hline-0.0098 & 0.1022 & -0.0021 & 0.0042 & -0.0471 & -0.0106 & -0.0011 \\
$(-0.7187)$ & $(0.5692)$ & $(-1.2837)$ & $(0.3695)$ & $(-2.8951)$ & $(-1.9189)$ & $(-0.2404)$ \\
\hline
\end{tabular}

The results show that higher idiosyncratic volatility at the end of the previous month is associated with more positive excess returns in the following month, but this result is statistically insignificant at all levels. This result is consistent with the results of portfolio sorts in Table 4. We find a significant momentum effect, but the sign of the coefficient is negative, which means that past long-term winners will be losers next month, thus rendering this a long-term reversal. We also find a significant short-term reversal, meaning that past short-term winners will be losers next month. We note that the short-term reversal effect is stronger than the long-term one.

To investigate the relationship between aggregate idiosyncratic volatility and market return as well as between aggregate market volatility and market return, we regress market return on lagged volatility. In Table 6 we report the results of these predictive regressions. The t-statistic is shown in parentheses.

Table 6. Predictive regressions of market return

\begin{tabular}{lllll}
\hline Intercept & $\mathrm{IV}^{\mathrm{VW}}$ & $\mathrm{IV}^{\mathrm{EW}}$ & $\mathrm{VOL}$ & Adjusted $^{2}$ \\
\hline-0.0052 & 1.2299 & & & -0.0015 \\
$(-0.2098)$ & $(0.9332)$ & & & -0.0113 \\
0.0201 & & -0.2010 & & -0.0035 \\
$(0.3533)$ & $(-0.0883)$ & -1.3450 & \\
0.0575 & & $(-0.8280)$ & \\
$(1.0962)$ & & & & \\
\hline
\end{tabular}

We find that neither $\mathrm{IV}^{\mathrm{VW}}, \mathrm{IV}^{\mathrm{EW}}$ nor VOL can predict market return since their slope coefficients are statistically insignificant and the respective adjusted $\mathrm{R}^{2}$ are negative.

Finally, to check for the presence of a trend in $\mathrm{IV}^{\mathrm{VW}}, \mathrm{IV}^{\mathrm{EW}}$ and VOL, we regress them on a linear time trend variable. In Table 7 we report the estimates of the time trend from these regressions.

Table 7. Trend

\begin{tabular}{lll}
\hline & Trend coefficient $\times 10^{5}$ & t-statistic \\
\hline $\mathrm{IV}^{\mathrm{VW}}$ & -1.6728 & -0.4671 \\
$\mathrm{IV}$ & 2.6611 & 1.2795 \\
$\mathrm{VOL}$ & -7.7232 & -2.7336 \\
\hline
\end{tabular}

We find no trend in neither $\mathrm{IV}^{\mathrm{VW}}$ nor $\mathrm{IV}^{\mathrm{EW}}$ over the sample period. We also find that there is a strong negative trend in VOL.

\section{Conclusion}

In this paper we study idiosyncratic volatility in the Vietnamese stock market between July 2007 and February 2015. Using a sample of 889 Vietnamese companies we construct Fama and French (1993) risk factors for Vietnam and calculate idiosyncratic volatility which is defined as the standard deviation of the residuals from the Fama and French (1993) model. Using portfolio sorts on the basis of past months' idiosyncratic volatility, we show that there is no relationship between the idiosyncratic volatility and average returns in the Vietnamese market. This result is also confirmed using Fama-MacBeth regressions including various control variables such as firm size, market-to-book value ratio, reversal, momentum and firms' beta. Our results also indicate that neither the aggregate market volatility, the aggregate idiosyncratic volatility nor can predict market returns. Finally, we find no trend in idiosyncratic volatility and a decreasing trend of market volatility over the sample period. In addition, we find strong evidence of both short as well as long term reversal in Vietnam stock market during the sample period. We hypothesise that the reversal effect is due to investors' overreaction to news as well as unjustified optimism or pessimism about future earnings. We believe it would be worthwhile to identify the nature of the reversal effect in Vietnam market and to disentangle the effect of investors' overreaction to news 
which we leave for future research.

\section{Acknowledgements}

This research was funded by a grant from University of Economics Ho Chi Minh City.

\section{References}

Ang, A., Hodrick, R. J., Xing, Y., \& Zhang, X. (2006). The cross-section of volatility and future returns. Journal of Finance, 61(1), 259-299. http://dx.doi.org/10.1111/j.1540-6261.2006.00836.X

Ang, A., Hodrick, R. J., Xing, Y., \& Zhang, X. (2009). High idiosyncratic volatility and low returns: International and further u.s. evidence. Journal of Financial Economics, 91(1), 1-23. http://dx.doi.org/10.1016/j.jfineco.2007.12.005

Avramov, D., Chordia, T., Jostova, G., \& Philipov, A. (2013). Anomalies and financial distress. Journal of Financial Economics, 108(1), 139-159. http://dx.doi.org/10.1016/j.jfineco.2012.10.005

Bali, T. G., Cakici, N., \& Whitelaw, R. (2011). Maxing out: Stocks as lotteries and the cross-section of future returns. Journal of Financial Economics, 99(2), 427-446. http://dx.doi.org/10.1016/j.jfineco.2010.08.014

Bali, T. G., Cakici, N., Yan, X., \& Zhang, Z. (2005). Does idiosyncratic risk really matter? Journal of Finance, 60(2), 905-929. http://dx.doi.org/10.1111/j.1540-6261.2005.00750.x

Banz, R. W. (1981). The relation between return and market value of common stocks. Journal of Financial Economics, 9(1), 3-18. http://dx.doi.org/10.1016/0304-405X(81)90018-0

Barberis, N., \& Huang, M. (2001). Mental accounting, loss aversion, and individual stock returns. Journal of Finance, 56(4), 1247-1292. http://dx.doi.org/10.1111/0022-1082.00367

Barinov, A. (2011). Idiosyncratic Volatility, Growth Options, and the Cross-Section of Returns. Working Paper, University of Georgia. http://dx.doi.org/10.2139/ssrn.1028869

Bekaert, G., Hodrick, R., \& Zhang, X. (2012). Aggregate idiosyncratic volatility. Journal of Financial and Quantitative Analysis, 47(6), 1155-1185. http://dx.doi.org/10.1017/S0022109012000543

Black, F., Jensen, M. C., \& Scholes, M. (1972). The capital asset pricing model: Some empirical tests. In M.C. Jensen (Ed.), Studies in the theory of capital markets (pp. 79-121). New York, NY: Praeger.

Boehme, R., Danielson, B., Kumar, P., \& Sorescu, S. (2009). Idiosyncratic risk and the cross section of stock returns: Merton (1987) meets miller (1977). Journal of Financial Markets, 12, 438-468. http://dx.doi.org/10.1016/j.finmar.2009.01.004

Boyer, B., Mitton, T., \& Vorkink, K. (2010). Expected idiosyncratic skewness. Review of Financial Studies, 23(1), 169-202. http://dx.doi.org/10.1093/rfs/hhp041

Brandt, M. W., Brav, A., Graham, J., \& Kumar, A. (2010). The idiosyncratic volatility puzzle: Time trend or speculative episodes? Review of Financial Studies, 23(2), 863-899. http://dx.doi.org/10.1093/rfs/hhp087

Brown, G., \& Kapadia, N. (2007). Firm-specific risk and equity market development. Journal of Financial Economics, 84(2), 358-388. http://dx.doi.org/10.1016/j.jfineco.2006.03.003

Campbell, J. Y., Lettau, M., Malkiel, B., \& Xu, Y. (2001). Have individual stocks become more volatile? An empirical exploration of idiosyncratic risk. Journal of Finance, 56(1), 1-43. http://dx.doi.org/10.1111/0022-1082.00318

Cao, C., Simin, T., \& Zhao, J. (2008). Can growth options explain the trend in idiosyncratic risk? Review of Financial Studies, 21(6), 2599-2633. http://dx.doi.org/10.1093/rfs/hhl039

Chen, J., \& Petkova, R. (2012). Does idiosyncratic volatility proxy for risk exposure? Review of Financial Studies, 25(9), 2745-2787. http://dx.doi.org/10.1093/rfs/hhs084

De Bondt, W. F. M., \& Thaler, R. H. (1985). Does the stock market overreact? Journal of Finance, 40(3), 557-581. http://dx.doi.org/10.2307/2327804

Ewens, M., Jones, C. M., \& Rhodes-Kropf, M. (2013). The price of diversifiable risk in venture capital and private equity. Review of Financial Studies, 26(8), 1854-1889. http://dx.doi.org/10.1093/rfs/hht035

Fama, E. F., \& French, K. R. (1992). The cross-section of expected stock returns. Journal of Finance, 47(2), 427-465. http://dx.doi.org/10.2307/2329112

Fama, E. F., \& MacBeth, J. (1973). Risk return and equilibrium: Empirical tests. Journal of Financial Political 
Economy, 71, 607-636. http://dx.doi.org/10.1086/260061

Fama, E., \& French, K. R.(1993). Common risk factors in the returns on stocks and bonds. Journal of Financial Economics, 33(1), 3-6. http://dx.doi.org/10.1016/0304-405X(93)90023-5

Fink, J., Fink, K. E., Grullon, G., \& Weston, J. P. (2010). What drove the increase in idiosyncratic volatility during the internet boom? Journal of Financial and Quantitative Analysis, 45(5), 1253-1278. http://dx.doi.org/10.1017/S0022109010000487

Goyal, A., \& Santa-Clara, P. (2003). Idiosyncratic risk matters! Journal of Finance, 58(3), 975-1007. http://dx.doi.org/10.1111/1540-6261.00555

Irvine, P. J., \& Pontiff, J. (2009). Idiosyncratic return volatility, cash flows, and product market competition. Review of Financial Studies, 22(3), 1149-1177. http://dx.doi.org/10.1093/rfs/hhn039

Jegadeesh, N., \& Titman, S. (1993). Returns to buying winners and selling losers: Implications for stock market efficiency. Journal of Finance 48(1), 65-91. http://dx.doi.org/10.2307/2328882

Jiang, G. J., Xu, D., \& Yao, T. (2009). The information content of idiosyncratic volatility. Journal of Financial and Quantitative Analysis, 44(1), 1-28. http://dx.doi.org/10.1017/S0022109009090073

Lehmann, B. N. (1990). Residual risk revisited. Journal of Econometrics, 45, 71-97. http://dx.doi.org/10.1016/0304-4076(90)90094-A

Lintner, J. (1965). The valuation of risk assets and the selection of risky investments in stock portfolios and capital budgets. Review of Economics \& Statistics, 47(1), 13-37. http://dx.doi.org/10.2307/1924119

Malkiel, B. G., \& Xu, Y. (2004). Idiosyncratic risk and security returns. Working paper, Princeton University.

Malkiel, B.G., \& Xu, Y. (1997). Risk and return revisited. Journal of Portfolio Management, 23(3), 9-14. http://dx.doi.org/10.3905/jpm.1997.409608

Merton, R. C. (1987) A simple model of capital market equilibrium with incomplete information. Journal of Finance, 42(3), 483-510. http://dx.doi.org/10.2307/2328367

Nagel, S. (2005). Short sales, institutional ownership, and the cross-section of stock returns. Journal of Financial Economics, 78(2), 277-309. http://dx.doi.org/10.1016/j.jfineco.2004.08.008

Tinic, S. M., \& West, R. R. (1986). Risk, return, and equilibrium: A revisit. Journal of Political Economy, 94(1), 126-147. http://dx.doi.org/10.1086/261365

Wei, S. X., \& Zhang, C. (2006). Why did individual stocks become more volatile? Journal of Business, 79(1), 259-292. http://dx.doi.org/10.1086/497411

Xu, Y., \& Malkiel, B. G. (2003). Investigating the behavior of idiosyncratic volatility. Journal of Business, 76(4), 613-644. http://dx.doi.org/10.1086/377033

\section{Copyrights}

Copyright for this article is retained by the author(s), with first publication rights granted to the journal.

This is an open-access article distributed under the terms and conditions of the Creative Commons Attribution license (http://creativecommons.org/licenses/by/3.0/). 